\title{
Depiction of hairstyle, reflection of identity? Some considerations concerning Neolithic depictions of hairstyles in the Anzabegovo - Vršnik and Velušina - Porodin cultural milieu
}

\author{
Alenka Tomaž \\ Institute for Archaeology and Heritage, Faculty of Humanities, University of Primorska, Koper - Capodistria, SI \\ alenka.tomaz@fhs.upr.si
}

\begin{abstract}
The phenomenon of Neolithic figurines and other anthropomorphic representations depicting humans with styled hair is an issue that has been generally overlooked in research. Their occurrence in Neolithic contexts all around Southeast Europe is fascinating in itself, and the same holds for the territory of the Anzabegovo - Vršnik and Velušina - Porodin cultural milieus, which is the case study presented in this article.
\end{abstract}

KEY WORDS - Neolithic; anthropomorphic figurines; depiction of hair; Republic of Macedonia

\author{
Upodabljanje pričeske kot odsev identitete? Nekaj pomislekov o upodobitvah \\ pričesk v neolitskem kulturnem okolju skupnosti Anzabegovo - Vršnik \\ in Velušina - Porodin
}

IZVLEČEK - Fenomen neolitskih figurin in drugih antropomorfnih predstavitev, ki upodabljajo ljudi s pričeskami, je tema, ki je bila pri raziskavah na splošno spregledana. Njihova prisotnost $v$ neolitskih kontekstih jugovzhodne Evrope je fascinantna že sama po sebi, kar velja tudi za skupnosti kulturnega okolja Anzabegovo-Vršnik in Velušina-Porodin, ki sta osrednji temi pričujočega teksta.

KLJUČNE BESEDE - neolitik; antropomorfne figurine; podobe pričesk; Republika Makedonija

\section{Introduction}

"Her hairstyle must have been magnificent" was my initial thought when I first saw the famous anthropomorphic representation with an outstanding depiction of styled hair from Tumba Madžari (Fig. 1). At that time, the visualisation of her hair had such a strong impact on me that it was not at all difficult to picture how she wore her hair almost eight thousand years ago. It was not this figurine that was travelling through my mind; it was a person with a real hairdo. Her long hair was knitted in a very artistic style. On both sides of her head, the long hair was neatly tied at the back, where strands of hair were braided in the form of a number of 'dragonfly' wings. A straight plait running from the top of the head covered the inner part of these extraordinary strands. To complete her appearance, short tiny locks of red painted hair adorned her face. It was a brief, but lovely moment, and I am convinced that many of the visitors shared my emotions by just looking at her.

Another extremely important and fortunate circumstance regarding my personal interest in representations of Neolithic hairstyles, however, is my involvement in archaeological excavations at the Govrlevo 

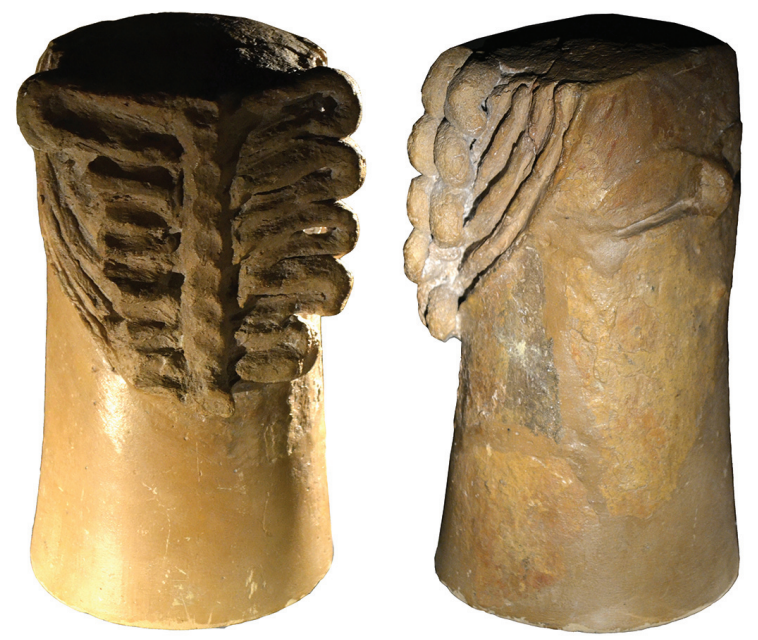

Fig. 1. Cylinder from house model from Tumba Madžari, Skopje from the Archaeological museum of Macedonia (photo by Mateja Ravnik).

site near Skopje conducted by Miloš Bilbija for many years now (Bilbija 1985.36). My participation in the excavation campaigns between 2004 and 2010 had a great influence on my views concerning this topic. The tiny fragments of figurine heads and other anthropomorphic representations discovered on a daily basis during the excavations exhibited such a great diversity in the way hair is depicted that it is possible that they are all unique.

The phenomenon of Neolithic figurines and other anthropomorphic representations depicting humans with hairstyles is an issue that has generally been overlooked in the history of research, but it is, I believe, very fascinating. In this article, I will explore some considerations concerning the depiction of hairstyles in Neolithic contexts. Although this theme has much broader theoretical connotations and could probably offer a much clearer insight if the whole Southeastern Europe were taken into consideration, I have limited myself to the territory of 'Anzabegovo - Vršnik' and the Velušina - Porodin cultural milieus, due to the aforementioned moments (Fig. 2).

Both cultural milieus represent the first Neolithic communities in a quite large territory (Garašanin 1979a; 1979b; Sanev 2004; 2006; Tasić 2006; Zdravkovski 2006a; 2008). Although they are both connected with the foundations of the Neolithic period in what is now the Republic of Macedo- nia, they reached their maximum cultural expression as well and territorial peak in the Middle Neolithic. Contexts ascribed to the Anzabegovo - Vršnik cultural milieu are mostly located in the Upper Vardar region including the Skopje region, Ovče pole, Polog and the valleys of the Bregalnica and Lakavica rivers, while contexts connected with Velušina Porodin cultural milieu are generally found in the wider area of Pelagonija. According to the few ${ }^{14} \mathrm{C}$ dates available, the above-mentioned cultural expressions can be viewed as manifestations of the late $7^{\text {th }}$ and $6^{\text {th }}$ millennium $\mathrm{BC}$.

But first, let us look at hair, its meaning and related practices in the recent past, as well as in today's societies.

\section{Hair, its meaning and related practices in the recent past}

Hair is a biological polymer, and thus a part of the human body, but its appearance always has cultural implication as well. How hair is styled is culturally significant; short or long, loose or tied together, shaved or unattended, etc. In a way, hairstyle constantly reflects a society and its cultural sphere as well as relationships in it. Throughout history, people have cared about their appearance and tried to find ways to personalise their looks; however, all these personal attempts are also socially and cultu-

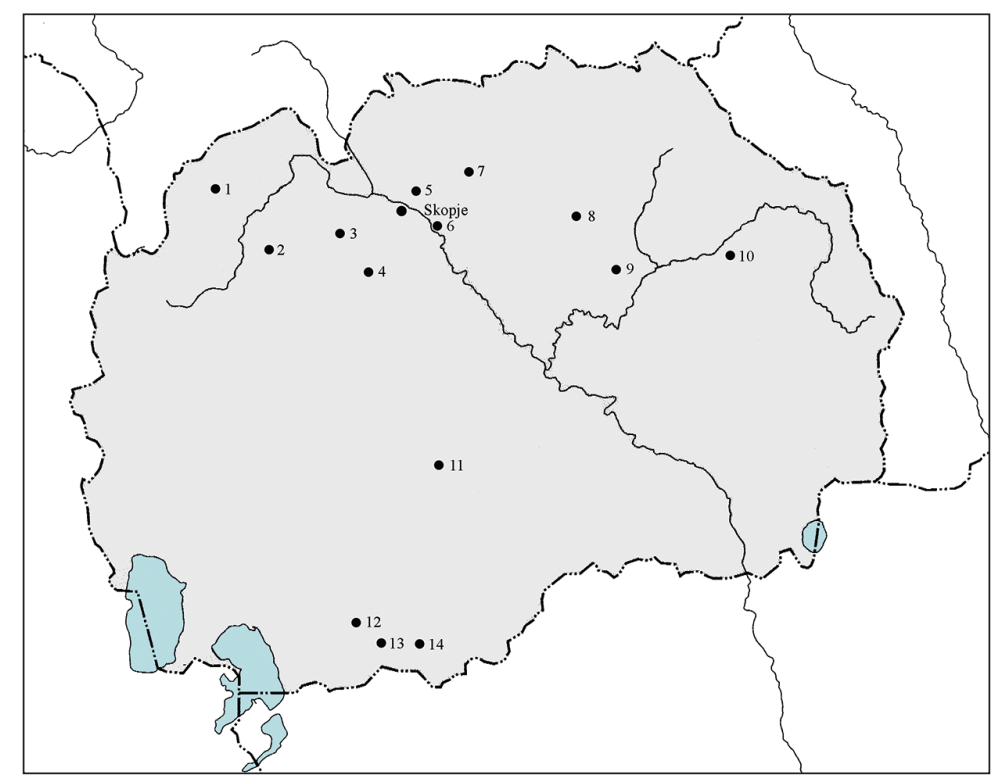

Fig. 2. The region of Anzabegovo/Vršnik and Velušina/Porodin cultural milieu with Neolithic sites mentioned in the text: 1 Tumba Dolno Palčište; 2 Tumba Stenče; 3 Govrlevo; 4 Zelenikovo; 5 Tumba Madžari; 6 Tumba Čair; 7 Mrševci; 8 Rug Bair; 9 Anzabegovo - Barutnica; 10 Vršnik; 11 Gjumušica; 12 Tumba Optičari; 13 Veluška tumba; 14 Tumba Porodin (created by Aleš Ogorelec). 
rally predisposed. In a way, hair can be regarded as a key aspect of appearance, since it is permanently on view if not deliberately covered, removed or lost. Throughout history, people have been willing to groom, adorn and also remove their hair, and for this purpose also spend time, energy and money, as well to sometimes undergo lengthy and uncomfortable procedures (Sherrow 2006.XXI).

When going deeper into history and observing modern societies, we become aware of how important hair has always been and still is in all segments of a given society (Olivelle 1998; Dikötter 1998; Ebersole 1998; Bryer 2000; Cheng 1998; Cox, Widdows 2005; Hiltebeitel 1998; Miller 1998). In the correlation with the anthropological concept of the body as being three partite entities, the individual body, the social body and the body politic, B. Miller proposed that hair should be conceptualised in the same manner as "individually experienced hair, socially symbolic hair and political hair" (Miller 1998.281). These three concepts of hair can perhaps help us to look more systematically at some of practices related to hair that are known from history or in present-day societies that are closely connected with individual, social or political undertones. However, the practices discussed will be very limited, since there are so many throughout history and in the modern world that it is quite impossible to present them even in a slightly wider perspective.

According to the first written accounts on the history of Africa, hair had a special spiritual connotation in African cultures. Many saw the head as a centre of control, communication and identity in the body. Hair was regarded as a source of power that embodied the individual. Since it rests on the uppermost part of the body, hair itself was a means for communicating with divine spirits. Hair also has a strong social and sexual connotation. Most societies regard long, thick, neatly styled hair on young women as a sign of health, respectability, and fertility. On the other hand, unkempt hair could be a sign of illness, mourning or antisocial behaviour. Hair played an important role in many rituals and customs, especially in naming ceremonies or funerals. African hairstyles could reveal a person's age, birthplace, clan membership, socioeconomic and marital status, as well as occupation. For example, among the Masai, members of the group wore different hairstyles according to their position in society. Women and children were usually shaved; warriors wore long braids dyed with red clay, while community leaders wore the most elaborate hairstyles (Sherrow 2006.12-15).
For centuries in Japan, hairstyle has signified a person's marital status, social class, age, occupation and/ or religious affiliation. During the Meiji period, for example, unmarried women wore butterfly hairstyles, while with the marriage hairstyle changed to a different type of bun (Sherrow 2006.220). A similar situation has been documented in China, where hairstyles may have reflected a person's social class, age, gender, religion, occupation and the customs in their communities. In both cases, unattended and neglected hair was a sign of illness or grief. The significance of women's hair in Japanese culture is also clearly manifested through the well-known proverb "Hair is women's life" (Sherrow 2006.220).

A variety of hairstyle traditions occurred in ancient societies in pre-Columbian America; among the Aztecs, for example, hairstyle indicated age and social status (Sherrow 2006.238). Native Americans in North America thought that their hair had a special spiritual significance. They also believed that if their hair came into the possession of enemies, the enemies would have power over them. Various hairstyles were adopted by the different Native American tribes. Also interesting is the case of Hopi women, who braided their hair into a single plait after marriage. Before marriage but after reaching the age when they were ready for marriage, young women wore a distinctive, whorled 'squash blossom' hairstyle resembling butterfly wings on each side of the head. This hairstyle was worn in a coming-of-age ceremony for young Hopi girls, and sometimes they are still worn today (Sherrow 2006.288).

Hairstyles of men and women's hairstyles have often differed greatly throughout history, and the styles of both have varied with changing fashions. Usually, some styles have been considered as 'feminine' and others as 'masculine'; however, women's hair has been worn longer than men's during almost all periods and in all cultures. In some eras and in some cultures, women's hair was bound or covered, especially after marriage. The roots of this practice are closely connected with early Judeo-Christian attitudes to women's hair (Sherrow 2006.XXII), which influenced at large women's hairstyles in European society, particularly during the Middle Ages. The changing habits of hair styling due to marriage are also known in the Balkans; there are some interesting instances from around Gaćište from the first half of the 20th century, when according to photographic archives, the premarital hairstyles of young girls were extremely elaborate compared to those of married women (Jurković 2008.24). 
It is known that in many instances religion or other religious practices do have a direct influence on hairstyles. For example, the hair and beard of Sikh men may never be cut. An adult Sikh man is recognised by his long hair and beard. The symbolism of this treatment of hair practice lies within the historical context between $15^{\text {th }}$ and $18^{\text {th }}$ Century A.D. in Northern India. Coming from the background of devotional religion, early Sikh gurus deliberately drew the contrast between Sikh bodily symbols and those of traditional Hindu renouncer with his shaven head and others (Olivelle 1998.36-37). In fact, the shaving of heads as well as the whole body is also a practice encouraged by some religious beliefs, such as in Hindu, as already stated, and among Buddhist priests and nuns (Sherrow 2006.220), etc. However, in some strict religions, such as among the Amish group or Islam, women are forbidden to uncover their hair (Sherrow 2006.35, 326).

Hair, or rather hairstyle, has also been decreed by the state, such as the Manchu government's 1644 decree on hairstyle. A decree proscribed the shaving of the men's forehead and braiding their hair into a queue. The Manchu rulers were almost certainly unique in the importance they attributed to the political significance of men's coiffure, and in their willingness to compel by force such a large a population to adopt an alien style. Many who did not follow the rules were, in fact, killed (Cheng 1998.123142). According to Cheng, this case reveals how hair became a means of social control and a focus of cultural and politic conflict. In traditional, China, men's long and plaited hair epitomised the Confucian norm of filial piety, Han culturalism and magical power. During the Qing dynasty, the shaved forehead and queue style symbolised Manchu autocratic authority and its cultural dominance (Cheng 1998.138).

Equally important from the perspective of hairstyle practices is the removal of hair. This practice can be traced in the historical sources all the way to Ancient Egypt, where all members of the higher classes, male and female, shaved their heads and wore wigs (Sherrow 2006.43). Shaving of hair is also a usual practice among men in some tribes in Asia, while women in India and Africa may shave their head for a particular reason, such as in mourning, for example. Indian traditions advise that a widow shave her head, stop wearing jewellery and dress in plain white or dark clothing (Sherrow 2006.43). In this way, the widow is socially separated from society (Olivelle 1998.20). The practice of removing the hair from the whole female body is expected in some cultures at certain times, such as upon marriage. Some Orthodox Jewish women cut their hair upon marriage and then conceal it with a wig of false hair, called a 'sheitel' (Sherrow 2006.326). The removal of hair from the head in some cultures has indicated social status. For example, in a number of instances, slaves were shaved, thereby indicating their low status. Another case worth mentioning is when the removal of hair is intended to humiliate and subordinate person or as a punishment, which has a long history and persisted into the modern era. For example, after Second World War, French woman who had collaborated with Nazi soldiers were publicly humiliated when their heads were shaved by members of the community (Sherrow 2006.XXV). In many cultures, the same fate also befell adulterous women or women who committed a crime (Sherrow 2006.220). In Asia, there is also a documented practice of criminals being shaved, which forced them to live the life of beggars outside society (Olivelle 1998.20).

Hair also has many symbolic connotations in a range of different societies. One that has been quite widely accepted is connected with grass and fertility. An extremely important quality of hair is that it grows continuously. Besides nails, hair is the only part of the natural body with this characteristic. Because of this the hair on the human head is in many cultures compared to grass. Both grow again if they are cut, both testify to the 'fertility' of their hosts, and in a way they are visually quite similar. Because of these visual connotations, hair is in often symbolically closely related to fertility (Olivelle 1998.36-37).

Another, very famous, example of hair symbolism is found in the story of Samson and Delilah, in which healthy hair is a symbol of strength. Hair symbolism can also be seen in many other cases, and sometimes the significance of hair in different cultures can be viewed and expressed in completely opposing ways. No single or unique meaning can be found in this vast range of ways in which hair is treated. It is in the very nature of the dialectic character of cultural products that the same fact or act may have different meanings for different individuals or groups (Olivelle 1998.31).

\section{Neolithic anthropomorphic representations}

The occurrence of figurines and other anthropomorphic representations depicting humans with hairstyles in Neolithic contexts throughout South-east Europe is fascinating in itself, and the same holds for the territory of the Anzabegovo - Vršnik and Ve- 
lušina - Porodin cultural milieus (Fig. 2). They give us a very good study basis from which to begin our research; however, let us look first at some general data.

Figurines as well as other anthropomorphic representations, whole or fragmented, are quite numerous in Neolithic contexts in the study area (Sanev 2004; 2006; Kolištrkoska Nasteva 2005; Zdravkovski 2006a; 2006b; 2008; Mitrevski 2003; Naumov 2006; 2007; 2008; 2009). According to Naumov, 274 published specimens have been published (Naumov 2009.47-58, Fig. 6.1), and many are still not published 1 . The figurines and other anthropomorphic representations vary greatly in form and representational technique on the one hand and great homogeneity on the other, as we shall see in the following section. There are three basic typological groups, with a variety of subgroups (Sanev 2006.172), based on the typological character and artistic concept of the objects' shape: anthropomorphic figurines, anthropomorphic dishes and anthropomorphic altars.

All these anthropomorphic figurines are miniature representations of the human body, male, female, and also ones with no indication of gender. They depict various body positions, standing, sitting or reclining. Most of them are made of fired clay with a very fine-grained composition; only a few are made from marble and quartz (Sanev 2006.173). In general, female are more frequent than male representations. Sanev managed figurines into several subgroups based on body shape. Female figurines can be divided into several different types: pear-like statuettes, statuettes with elongated necks, sitting miniature statuettes, two-part sitting statuettes, kneeling statuettes, standing statuettes and pillar statuettes. Anthropomorphic male statuettes occur only in two basic types: sitting and standing (Sanev 2006. 174-181). Figurines are usually discovered settlement areas, either on house floors together with pottery and other artefacts, or in the close vicinity of the so-called 'house domain', but they do not appear in other types of archaeological context.

Anthropomorphic dishes are very few in number; however, they also display some important characteristics concerning depictions of the human body (Naumov 2009.59-72). These dishes can be found in the Anzabegovo - Vršnik cultural milieu and thus constitute yet another aspect of body representation.
The next group of anthropomorphic representations according to Sanev are anthropomorphic altars. This group of items gives the Middle Neolithic Anzabegovo - Vršnik cultural milieu a kind of individual and unique quality. It is a kind of hybrid form of two elements: the so-called 'house model' in the lower part of the sculpture and a highly structured representation of human body in the upper segment. The 'house model' is a kind of rectangular form, in some cases perforated on all four sides. These perforations can be different shapes: oval, rectangular, circular etc. Small circular perforations can also be found on the upper corners of the 'house model'. In most cases, representations of the human body in these anthropomorphic altars are formally very homogeneous from the artistic point of view. The trunk can be depicted in very realistically, with breasts, abdomen and symmetrically outstretched arms, or with no particular insignia. The head is frequently in the form of a long cylinder, and circular, oval or rectangular in cross-section. The face is depicted very schematically, usually with highly accentuated arches above the eyes. The eyes are frequently portrayed only with an incised line, although they are sometimes depicted more elaborately. The mouth is represented only rarely. Most were discovered at Tumba Madžari, and also at some other sites in the Skopje region: at Govrlevo, Sredselo in Mrševci, Zelenikovo, Tumba Čair and outside the region of Dolno Palčište, Anzabegovo and Rug Bair (Kolištrkoska Nasteva 2005; Sanev 2006; Zdravkovski 2008). This type of anthropomorphic representation has many different names and descriptions in publications, such as the already mentioned 'anthropomorphic altars' (Sanev 2006.182), then 'altar with an image of the Great Mother' (Kolištrkoska Nasteva 2005. 60), anthropomorphic model of the house with chimney depicting a woman down the waist (Kolištrkoska Nasteva 2005.61), 'The Great Mother' (Zdravkovski 2008.192; Kolištrkoska Nasteva 2005.62), 'The Great Mother of God' (Sanev 2008.188), 'models of figurine/houses' (Naumov 2009.47-58), etc.

On the basis of typological classification and account of artistic-aesthetic differences, Sanev divided these sculptures into two basic groups. The first group consists of those depicting people with outstretched arms, placed on house models with decorated openings on the sides. The second group comprises altars with human images without arms, placed on house models (Sanev 2006.188). Another division based on the wall finishing of the house models was

1 Any statistical interpretation of current data would therefore not give us a referential overview. 
also proposed: altars with a human image on a house model with carved walls and altars with a depiction of a human image on a closed-walled building ( $\mathrm{Sa}$ nev 2006.188-189).

Models of figurine-houses are usually found in settlements areas, whole or fragmented; according to the published data, they can be found in almost every studied 'house' assemblage. The abundance of these finds in settlement contexts and especially in 'house assemblages' led Sanev to the assumption that their presence in the house reflects the desire and obligation of each household to have one, which was provided while the house was being built (Sanev 2006.190). In any case, the most widespread interpretations of anthropomorphic altars are associated directly with cults and religion, since most authors see in these sculptures depictions of the 'Great Mother of the Gods' (Kolistrkoska Nasteva 2005; Sanev 2006, Zdravkovski 2008). The representation of the 'female principal', as Sanev puts it, was intended to approximate as closely as possible the narrative look of an actual woman of that time, and it included artistic effects linked to everyday life. According to Sanev, this is why some examples were made with elegant coiffure, adorned with bracelets, necklaces and other decorative details (Sanev 2006.187). Naumov's recent view is perhaps somewhat different, but very promising; by exploring several different aspects of figurine/houses, he concluded that these objects should be viewed as a matrix of a universal concept which is concentrated mostly around female regeneration and motherhood (Naumov 2009.47-58).

All three basic groups of anthropomorphic representations are indicative of Middle Neolithic contexts in the Skopje Valley and Pelagonia. In each group, the depiction of hairstyles can be observed in all the individual cases, as we shall see further on. In order to properly explore some issues of primary concern here, it is necessary to first explore some views on figurines in general.

Figurines are perhaps the most intriguing works of visual art found in Neolithic contexts thought-out the Balkan area, and they certainly receive a great deal of attention from the general as well as the specialist public. They are perhaps the most frequently exhibited artefacts in the exhibitions, many largescale publications have been devoted to different aspects of the figurines and other anthropomorphic representations and there are quite a lot of catalogue-like publications, in which overviews of archaeo- logical finds are presented in detail as well. And what is probably most important, they encourage researchers to constantly try to answer at least some of the questions concerning their production, use, function, meaning, role in society, etc. Since there are so many questions, there are also many different understandings and interpretations.

Authors provide us with several diverse views and interpretations concerning the above-mentioned aspects. Some authors see figurines as religious, ritual or some sort of cult devices; some connect them directly with an idea of a pantheon of gods and goddesses, with Maria Gimbutas being the actual promoter of this view (Gimbutas 1982; 1989; 1999). Other authors view them as the representations of everyday life; some see them as children's toys, etc. Views also differ on who made them, i.e. whether by men, women, priests, potters etc. Various accounts on the subject have already been presented elsewhere in detail (Bailey 2005; Sanev 2006; Hansen 2007). However, for our purpose it is important to emphasise at least some of the latest views that in my opinion work well within our theme.

In 2005, Douglass Bailey proposed, and later in 2008 developed, a rather new way of seeing Neolithic figurines, with some very instructive mechanisms, which enable us to observe and perhaps appreciate the figurines (Bailey 2005; 2008.9-18). In his opinion, figurines stimulate people (modern and Neolithic) to think and above all to make assumptions about themselves and other people. The process of miniaturisation and abstraction are to achieve such stimulation. In a way, all figurines are miniature representations of the human body. And with the practice of miniaturisation, the decision about which features to represent and which to omit comes as well. Reduction in size is always accompanied by a reduction in the number of features represented (Bailey 2008.10). Bailey also argues that, as a consequence of representational absence, when people make, look and handle miniature representations and otherwise engage with the miniature world, they gain access to other worlds and alternative realities, as shown in a number of examples (Bailey 2005; 2008.10).

In Bailey's view, we should comprehend figurines as philosophies, as entities that make people question who they are, what they look like, how they are similar to some but different from others (Bailey 2005. 197-204; 2008.10); and to tackle all these questions, he proposed looking at Neolithic figurines in terms 
of the concept of stereotypes and the process of stereotyping (Bailey 2008.10). In the simplest terms, he sees stereotypes as conventional, formulaic and oversimplified conceptions or images which propose a set of fixed, unvarying ways to understand the whole world around us. At the broader level of social psychology, stereotypes are seen as inherent to human nature and society. They are understood as a critical apparatus with which people make sense of the world around them and of their relations with others whom they encounter, interact with and are dependent on (Bailey 2008.11). Stereotypes work within people's conceptions of what is normal or natural. They are part of the ways in which communities create and sustain a shared sense of the proper limits of what is accepted as legitimate and proper. Stereotypes also allow the construction of social groups by maintaining and reproducing norms and conventions of behaviour, identity and value, so they enable people to experience the world in a particular, perhaps more efficient, manner. Through their own mechanisms stereotypes can be regarded as fictions and illusions, since they do not record reality, but create a record of constructed perceptions within existing relations of powers and orders.

\section{Overview of elements depicting hairstyle}

Let us look more systematically at depictions of hairstyles, bearing all the foregoing in mind. The cylinder depicting the head of the so-called 'Great Mother' from house 6 in Tumba Madžari (Fig. 1; Zdravkovski 2008.176), described at the beginning, is not the only depiction of coiffure found in the Republic of Macedonia, of course. There are quite a few of them, and they appear in all three basic groups of anthropomorphic representations; however, in our opinion, the most of depictions of hair can be seen on various figurines or statuettes and on so-called 'anthropomorphic altars' (Figs. 3 and 4).

\section{Depiction of hairstyles on figurines 2}

If we look closely at figurines, we can see that various hairstyles are depicted in some variety, with very expressive although in a way stylised precision. The depictions were executed with diverse techniques. The choice of representation technique most likely depended on the maker's wish to represent a particular hairstyle. For portraying a couple or more buns (Fig. 3.1-4), as seen on the figurines from Anzabegovo (Gimbutas 1976.Fig. 144), Porodin (Kolištrko- ska Nasteva 2005.21, 27), or Tumba Optičari (Kolištrkoska Nasteva 2005.20), the application technique has been used; sometimes with combinations of incisions to draw closer attention to the final appearance. Hair-buns are usually depicted with rather small, circular appliqués. They appear in pairs and sometimes in larger number (Fig. 3.3). It may seem striking that this kind of hairstyle depictions, apart from the figurine from Anzabegovo, are very similar to anthropomorphic representations that are culturally connected with the Velušina - Porodin cultural milieu. It is also important to mention that this kind of depiction can also be found on anthropomorphic vessels (Sanev 2006.181, Fig. 21).

Another interesting depiction of hairstyle was found in Gjumušica near Prilep (Kolištrkoska Nasteva 2005.46). Depictions of long almost loose worn hair, tied together at the back just at their end, are depicted very exact precision in incisions technique (Fig. 3.6). However, not only long, but also short haircuts have been depicted in some cases, as for example on figurines from Tumba Čair, Tumba Stenče, and Tumba Madžari. All three examples show a very short, flat hair, with some indications of a side or central parting (Fig. 3.7-9). The depictions are completed with incisions; however, the widths and densities of incisions vary considerably in all three cases, such that they create completely different final appearances.

Another interesting depiction of hairstyle is seen on a figurine from Anzabegovo (Fig. 3.5). It, too, was achieved with incisions representing short, probably slightly curly hair. A completely different hairstyle is seen on another figurine, from Tumba Madžari, most likely depicting short but extremely curly hair (Fig. 3.10). In this case the hairstyle is achieved with the application technique; however, it is rather badly preserved. Interestingly, depictions of hair in the so-called anthropomorphic altars use this technique more frequently, or at least the examples are more numerous, as we shall see below.

\section{Depiction of hairstyles on anthropomorphic altars}

The other group of anthropomorphic representations in which hairstyles are depicted with great precision are so-called 'anthropomorphic altars' or 'models of figurine-houses', as already mentioned. Most of these objects were discovered at well-known Neolithic sites

2 In this present overview of depictions of hair on figurines, some specimens from Rug Bair (Hansen 2007.Taf. 151:2; Taf. 152:1, 2) were not considered relevant, since such depictions are somewhat unusual and could easily be viewed as some form of headgear. 


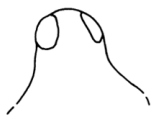

a

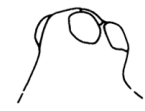

b

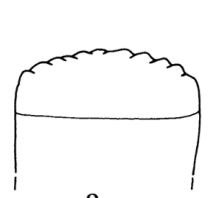

a

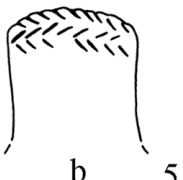

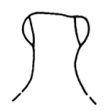

a

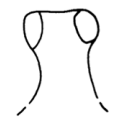

b 2

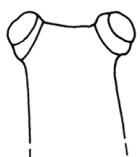

a

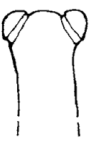

a

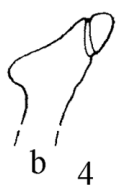

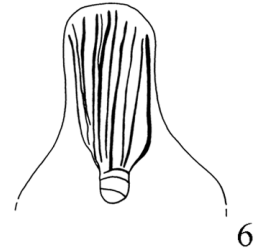

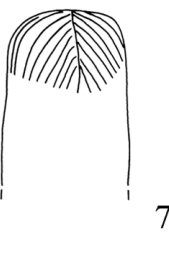

7
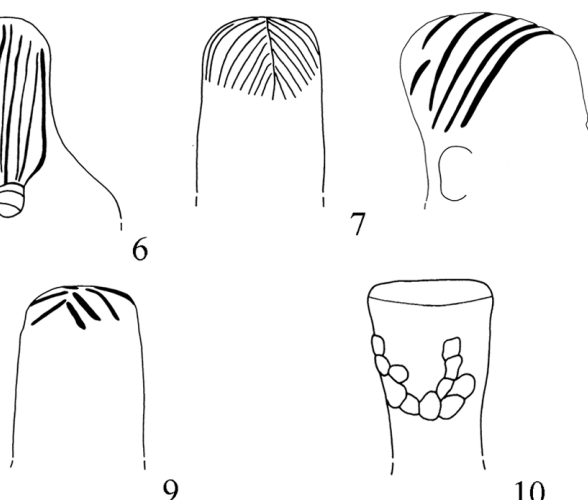

in the Skopje region of Tumba Madžari; some specimens were found at other sites. Apart from the remarkable depiction of hairstyle from house 6 from Tumba Madžari already described (Figs. 1 and 4.1; Sanev 2006.Fig. 28), some others are equally expressive and therefore important.

Several different ornamental techniques were used to complete the depiction of hair. Various incisions of different thickness and density were to portray flat or wavy hair (Fig. 4.2, 3, 5, 10, 11); however, the shape of the depiction is perhaps also enormously instructive when establishing the final outcome of the appearance. A cylinder from Tumba Madžari (chance find; Sanev 2006.Fig. 27) features a representation of swept-back hair achieved with wide incised lines extending from the top of the head towards the neck (Fig. 4.2). It is possible that some kind of bun was at the back of the head, but this was not preserved.

The hairstyle one a huge anthropomorphic head, also from Tumba Madžari (Kolištrkoska Nasteva 2005. 57 ) is very similar; however, some elements make this example unique. The incisions are quite wide and are complemented with small inside stitches, so that the final result looks like some kind of furrowed incision; the shape of the hairstyle, on the other hand, also differs somewhat. Some of the incisions on each side of the head were completed with a circular shape, so that it looks like some kind of coiled plait.

Fig. 3. Selection of different hairstyles depicted on anthropomorphic figurines (a - front view, $b$ - back or side view): 1 Tumba Optičari (after Kolišstrkoska Nastaseva 2005.20); 2 Veluška Tumba, Porodin (Kolištrkoska Nasteva 2005.21); 3 Tumba Porodin (Kolištrkoska Nasteva 2005.27); 4 Anzabegovo (Gimbutas 1976.Fig. 144); 5 Anzabegovo - Barutnica (Korošec, Korošec 1973.T. XI: 11); 6 Gjumušica, Prilep (after Kolištrkoska Nasteva 2005.46); 7 Tumba Čair, Skopje (Stojanova Kanzurova, Zdravkovski 2008.150-151); 8 Tumba Stenče, Polog (Stojanova Kanzurova, Zdravkovski 2008.154-155); 9 Tumba Madžari, Skopje (Stojanova 8 Kanzurova, Zdravkovski 2008.152153); 10 Tumba Madžari, Skopje (Kolištrkoska Nasteva 2005.26) (drawings by Janja Tratnik Sumi compiled from selected publications).

10

The hairstyle on the anthropomorphic representation from Govrlevo (Fig. 4.5) is also interesting, although it survived only in fragments. It looks as if light curly hair worn loose is depicted on the back of the head. A comparable or at least somewhat similar example is a specimen from Dolno Palčišče which has zigzag incisions portraying light curly hair of unknown length (Fig. 4.11). Another anthropomorphic representations with depiction of hairstyle was found at Tumba Madžari in quadrant 2, that was made with the incision technique (Fig. 4.10; Sanev 2006.Fig. 26). It has deep incisions forming a triangle running from the top of the head towards the neck which were made quite skilfully, showing probably smooth, loose hair combed towards the back of the head. Resembling an example already mentioned is another specimen found in house 5 at Tumba Madžari (Fig. 4.9; Sanev 2006.184). At first sight, it seems to have a great resemblance to the previous example, but a detailed examination of the item shows that the technique as well as the form depicted are not the same. Furthermore, it is more likely that another type of hairstyle was depicted in this case, showing a highly structured form of several plaits extending from the top and sides of the head towards the neck, where they are joined together in a triangle.

Extremely curly hair, almost like an 'Afro' look is generally shown with an additional triangular layer of clay running from the top of the head towards the neck, accompanied with numerous fingertips im- 

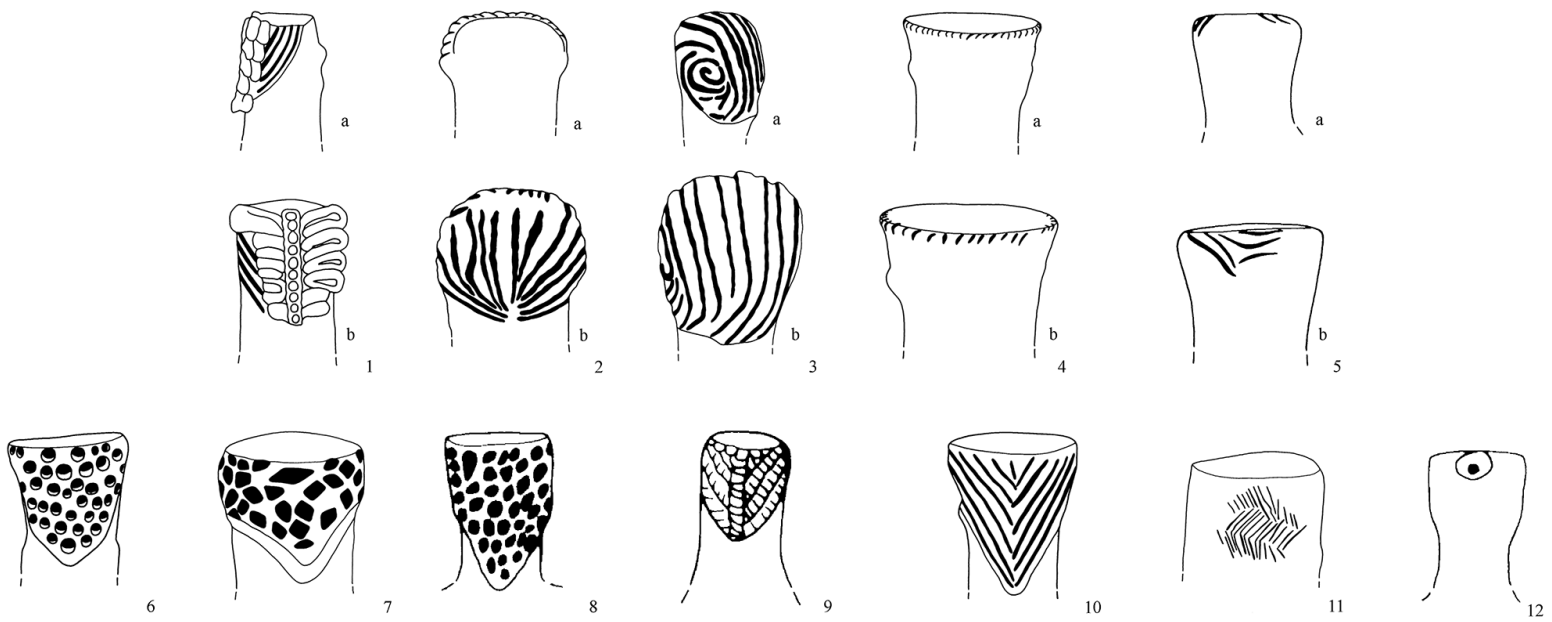

Fig. 4. Selection of different hairstyles depicted on anthropomorphic altars (a - front or side view, bback view): 1 Tumba Madžari, Skopje (Kolištrkoska Nasteva 2005.54); 2 Tumba Madžari, Skopje (Kolištrkoska Nasteva 2005.56); 3 Tumba Madžari, Skopje (Kolištrkoska Nasteva 2005.57); 4 Tumba Porodin (Kolištrkoska Nasteva 2005.70); 5 Govrlevo (Kolištrkoska Nasteva 2005.62); 6 Tumba Madžari, Skopje (Kolištrkoska Nasteva 2005.55); 7 Tumba Čair, Skopje (Kolištrkoska Nasteva 2005.69); 8 Tumba Madžari, Skopje (Kolištrkoska Nasteva 2005.58); 9 Tumba Madžari, Skopje (Kolištrkoska Nasteva 2005.60); 10 Tumba Madžari, Skopje (Kolištrkoska Nasteva 2005.65); 11 Tumba Dolno Palčište (Kolištrkoska Nasteva 2005.69); 12 Tumba Porodin (Kolištrkoska Nasteva 2005.59) (drawings by Janja Tratnik Šumi compiled from selected publications).

pressions (Fig. 4.6-8; Sanev 2006.Fig. 22-25). This type of depiction is known from Tumba Madžari and Tumba Čair. A similar result was also achieved with a simple application technique, whereby numerous, smaller and crowded circular appliqués were attached to the head, as seen on some fragments of a cylinder from Govrlevo.

Two other depictions of hair deserve our attention. They are both connected with finds that culturally belong to the Velušina - Porodin cultural milieu. In one instance, the hair has been rendered with small incisions all around the head (Fig. 4.4; Porodin; Kolištrkoska Nasteva 2005.70). In this, we can see perhaps a representation of very short flat hair, although this is a rather daring interpretation. In other case, a small application has been made at the back of the head, probably depicting a small bun (Fig. 4.12; Porodin; Kolištrkoska Nasteva 2005.59).

As we can see, this detailed review of how hair is depicted on anthropomorphic representations has provided some illustrative and instructive observations.

Firstly, the variety of hairstyle depictions in Neolithic contexts in the Anzabegovo - Vršnik and Velušina - Porodin cultural milieus is immense, as the ornamental techniques used.

Secondly, hair is depicted on all three basic groups of anthropomorphic representations: on figurines or statuettes, on anthropomorphic vessels and on socalled anthropomorphic altars or models of figurinehouses. However, it is important to note that depictions of hairstyle on anthropomorphic vessels are indeed rare.

Thirdly, some distinctions in hairstyle depiction are noticeable in relation to different groups of anthropomorphic representations. The diversity of hairstyle depictions is much more striking and expressive on anthropomorphic altars than on figurines. Also, the variety of techniques used to depict hair is much more complex within the first group then the other. Furthermore, the quality overtone in execution of depictions is noticeable as well, also in favour of anthropomorphic altars. Differences can also be observed in the stylistic approach to depicting hair. on figurines, hair is usually only schematically portrayed, while hair is actually more realistic represented on models of figurine-houses.

Fourthly, taking into consideration all depictions of hair, it is possible to see that although hair is shown in many different styles, some depiction have similarities; this is true of the form of the hairstyle depicted as well as the execution of it. In these cases, it may well be suggested that they actually represent hair styled exactly the same way.

Fifthly, there seems to be some sort of variation in depictions of hair between the Anzabegovo - Vršnik 
and Velušina - Porodin cultural milieus, although perhaps it is somewhat premature to be certain of this. However, there is some evidence that may make a good starting case. The hair depicted in the Velušina - Porodin cultural milieu seems to be limited to a small number of styles, in most cases involving different hair buns (Figs. 3.1-3 and 4.12), while in the Anzabegovo - Vršnik cultural milieu, where depictions of hairstyle are seen in multiple variations and ways, representing a rather diverse repertoire of different styles, hair buns representations are actually limited to one case only (Fig. 3.4).

If some of the representations are of actual hair styles, they can also point to intangible social activities going on in society which influenced the creation of at least some of these hairstyles. If it was real, the magnificent hairstyle fromTumba Madžari described above at the beginning was so multifaceted that it would definitely have required more than one person to be fashion it. We can suppose it very likely that in such cases these activities involved some kind of social bonding within the group.

\section{Conclusion}

The depiction of hair in Neolithic contexts in Southeast Europe is an exceptionally interesting theme, although it has perhaps not been discussed sufficiently. The theme is instructive and at the same time has great potential. Of course, it is in a way closely related to our understanding of anthropomorphic representations as such. Being aware of the broad array of questions that these items pose, our intention was not to answer them, but to open another chapter in this debate.

In his book about figurines, Douglas Bailey made what we believe to be an extremely important observation: "Neolithic figurines have at least two kinds of meanings. On the one hand they can be explained in terms of the particularities of their use or function, the reason for which they were made... On the other hand, there is a second meaning and it is this, which may prove to be the more significant for understanding the social realities of living in the Neolithic Balkans. This second meaning works at deeper level and has nothing to do with the intention of person who modelled, decorated or fired a figurine. It does not have anything to do with the ceremony(s)/game(s)/prayer(s) in which that figurine was used. It does not even have anything to do with whether or not that figurine was found in a pit, a building an oven, a burial or in the desk drawer of and antiques' collector. This second meaning is the position of the figurine as unintentional, but potent, manifestation of the body in the Neolithic communities" (Bailey 2005. 198-199).

The existing assemblage of figurines and other anthropomorphic representations from Neolithic contexts is in fact the biggest set of images associated with the human body known to us from the period. Even if it is true that understanding them through a concept of stereotypes and mechanisms of stereotyping remind us constantly that these representations are not representations of reality, but rather someone's perception of it, they are a most excellent legacy of what it meant to be human in this era.

Throughout the article, I have tried to look at depictions of hair in Neolithic contexts from two different cultural milieus (Anzabegovo/Vršnik and Velušina/ Porodin) from various perspectives, showing the archaeological data and their broader contexts within the anthropomorphic representations. The debate went further, touching the broad sphere of hair as such and its meaning within different societies and different cultural practices in order to obtain some insights into how the politics of hair works in different cultural milieus. In a way, this was very informative and helped us grasp at least some potential reasons why it would be so important for someone to portray hair with such accuracy and care. The best answer by far is because hair mattered, and because hairstyle must have played a very important role within the societies that produced these anthropomorphic representations. Although seeing them through the perceptions and manufacturing abilities of someone else, they give us an enormous insight into the ways and practices of the society and its views of the world as well as the body.

As we saw through our overview of how hair is treated in different cultures and societies, hair styling or lack of it, always had and still has a very expressive and indicative value; this was even more the case in the past, thanks to globalisation. According to written sources and extensive ethnographic data, hair style in different societies can indicate age, marital status, social status, rank, position in society, even occupation, etc. But how can these illustrations work if we also take into consideration the abovementioned archaeological evidence? Barbara Miller proposed that hair should be conceptualised as individually experienced hair, socially symbolic hair and political hair (Miller 1998.281). Is it possible to in- 
terpret our archaeological evidence through her understanding of the conceptualisation of hair. Can we assume that all the anthropomorphic representations depicting hair described herein actually reflect an individual's perception of an individual body, and hence represented an individual's coiffure, or are they depictions of Miller's other two types, socially symbolic or political hair?

Let us look first at the concept of the individual. The indications are contradictory. Above all, all the anthropomorphic representations considered here are in a way unique in form and execution, which supports the idea that these are individualised representations. However, on closer inspection, it becomes obvious that in all the examples the most central quality of personal identity of each human being is absent or depicted in extremely stylised manner almost careless, as Naumov pointed out (Naumov 2009). The faces of figurines are usually very schematic, with only a few incisions indicating the eyes and nose; in many instances, the face is completely absent. On the other hand, the faces on the models of figurine-houses are usually more elaborate; however, they do have some sort of standardised form of representation, such as in the eyes or eye arches, nose and sometimes mouth. From the choreographic point of view, they seem to have 'motionless' faces; they do not express any gesture or personal trait for that matter. Although there are some differences in facial depictions between figurines and models of figurine-houses, the fact remains that the faces in both cases do not articulate any elements of individual or personal identity. Hair depictions in our opinion support this idea, since there are some instances where hair is portrayed in almost identical mode, so that we can easily suppose that the depiction of the hair was intended to be universal rather than individualised. All these facts speak in favour of second and the third concept considered at the beginning; depictions of hair as a symbolic social marker and as political hair. There is some important evidence concerning the depiction of hair to support both of these concepts. When looking at the variety of hairstyles depicted on the figurines, which on some occasions assemble into some sort of fashion groups representing different modes of hairstyle, and taking into consideration also the fact that individual faces obviously did not matter, then these observations hold a quite a firm case in favour of socially symbolic depiction of hair. This observation may equally support the idea that the identity of some inner group expressed through hairstyle depictions, being this group of respective elderly women, young women before an initiation ceremony or something different. In addition, there has been also some evidence, which have already been brought up. It seems very likely that the Anzabegovo/Vršnik and Velušina/Porodin cultural milieus, both representing Middle Neolithic material traditions, which also differ in the other aspects of material and visual culture (Naumov 2009), preferred different hairstyles, at least as far as depictions of hair are concerned. In this case, one may also draw conclusions on the third conceptual entity, political hair.

In conclusion, I would like to address one other point concerning depictions of hairstyle or its absence. According to written sources and ethnographic data, the intentional removal of hair is a very common practice in many different cultures and societies. In a way, the removal of the hair is equally as important and illustrative as styling hair. From the archaeological point of view within our studied area, anthropomorphic representations that do not depict hair in any form at all are quite frequent (up to one fifth). Do such examples show the intentional removal of hair or something else? 


\section{References}

Bilbija M. 1985 (1987). Cerje Govrlevo. Arheološki pregled 26: 36.

Bailey D. W. 2005. Prehistoric Figurines, Representations and Corporeality in the Neolithic. Routledge, Taylor \& Francis Group. London and New York.

2008. The corporeal politics of being in the Neolithic. In D. Borić, J. Robb (eds.), Past Bodies, Body-Centered Research in Archaeology. Oxbow Books. Oxford: 9-18.

Bryer R. 2000. The History of Hair, Fashion and Fantasy down the ages. Philip Wilson Publishers. London.

Cheng W. 1998. Politics of the queue: Agitation and Resistance in the beginning and end of Qing China. In A. Hiltebeitel, B. D. Miller (eds.), Hair, its power and meaning in Asian cultures. State University of New York Press. Albany: 123-142.

Cox C., Widdows L. 2005. Hair \& Fashion. V\&A Publication. London.

Dikötter F. 1998. Hairy Barbarians, Furry Primates and Wild Men: Medical Science and Cultural Representations of Hair in China. In A. Hiltebeitel, B. D. Miller (eds.), Hair, its power and meaning in Asian cultures. State University of New York Press. Albany: 51-74.

Ebersole G. L. 1998. "Long Black Hair Like a Seat of Cushion": Hair Symbolism in Japanese Popular Religion. In A. Hiltebeitel, B. D. Miller (eds.), Hair, its power and meaning in Asian cultures. State University of New York Press. Albany: 75-103.

Garašanin M. 1979a. Grupa Anzabegovo Vršnik. In A. Benac (ed.), Praistorija Jugoslavenskih zemalja II, Neolitsko doba. Akademija Nauka i Umjetnosti Bosne i Hercegovine, Centar za Balkanološka ispitivanja. Sarajevo: 84106.

1979b. Veluško-Porodinska grupa. In A. Benac (ed.), Praistorija Jugoslavenskih zemalja II, Neolitsko doba. Akademija Nauka i Umjetnosti Bosne i Hercegovine, Centar za Balkanološka ispitivanja. Sarajevo: 107-114.

Gimbutas M. (ed.) 1976. Neolithic Macedonia, As reflected by Excavation at Anza, Southeast Yugoslavia. The Institute of Archaeology. University of California. Los Angeles.

1982. The Goddesses and Gods of Old Europe, 65003500 BC, Myths and Cult Images. New and updated edition. Reprint 2007. University of California Press. Berkeley, Los Angeles.
1989. The Language of the Goddess (Foreword by Joseph Campbell). Reprint 2006. Thames \& Hudson. New York.

1999. The Living Goddesses (ed. and suppl. Robbins Dexter, M.). University of California Press. Berkeley, Los Angeles.

Hansen S. 2007. Bilder vom Menschen der Steinzeit. Untersuchungen zur anthropomorphen Plastik der Jungsteinzeit in Kupferzeit in Südosteuropa. Archäologie in Eurasien Band 20. Deutsches Archäologisches Institut Eurasien-Abteilung. Verlag Philipp von Zabern. Mainz.

Hiltebeitel A. 1998. Introduction: Hair Tropes. In A. Hiltebeitel, B. D. Miller (eds.), Hair, its power and meaning in Asian cultures. State University of New York Press. Albany: 1-9.

Jurković J. 2008. Žensko češljanje prije i nakon udaje u Gaćištu. Baština, časopis gradskog muzeja Virovitica II(2): 24-30.

Kolištrkoska Nasteva I. 2005. Prehistoric Macedonian Ladies. Exhibition Catalogue. Museum of Macedonia. Skopje.

Korošec J., Korošec P. 1973. Predistoriska naselba Barutnica kaj Amzabegovo vo Makedonija. Izveštaj za izkopuvanjeto vo 1960. Dissertationes et Monographiae, tom XV. Arheološko društvo Jugoslavije. Arheološko društvo na Makedonija. Prilep.

Miller B. D. 1998. Afterword: Hair Power. In A. Hiltebeitel, B. D. Miller (eds.), Hair, its power and meaning in Asian cultures. State University of New York Press. Albany: 281-286.

Mitrevski D. 2003. Prehistory in Republic of Macedonia F.Y.R.O.M. In D. V. Grammenos (ed.), Recent Research in the Prehistory of the Balkans. Publications of the Archaeological Institute of Northern Greece, Nr. 3. Thessaloniki: 13-72.

Naumov G. 2006. Sadot, pećkata i kukjata vo simbolićka relacija so matkata $i$ ženata (neolitski predloški $i$ etnografski implikacii). Studia Mythologica Slavica 9. Ljubljana: 59-95.

2007. Housing the Dead: Burials inside houses and vessels from Neolithic Balkans. In C. Malone, D. Barowclough (eds.), Cult in Context. Oxbow Books. Oxford: 255-265.

2008. The Vessel as a Human Body: Neolithic anthropomorphic vessels and their reflection in later periods. In 
I. Berg (ed.), Breaking the Mould: challenging the past through pottery. British Archaeological Reports IS 1861. Archaeopress. Oxford: 93-101.

2009. Patterns and Corporeality: Neolithic Visual Culture from the Republic of Macedonia. British Archaeological Reports IS 1910. Archaeopress. Oxford.

Olivelle P. 1998. Hair and Society: Social Significance of Hair in South Asian Traditions. In A. Hiltebeitel, B. D. Miller (eds.), Hair, its power and meaning in Asian cultures. State University of New York Press. Albany: 11-49.

Sherrow V. 2006. Encyclopedia of Hair. A Cultural History. Greenwood Press. Westport.

Sanev V. 2004. Some characteristics of Anzabegovo-Vršnik cultural group in Macedonia. In S. Perić (ed.), The Neolithic in the Middle Morava Valley, The Central Pomoravlje in Neolithisation of South East Europe. Archaeological Institute, Regional museum Jagodina, Regional museum Paraćin. Belgrade: 35-48.

2006. Anthropomorphic Cult Plastic of Anzabegovo-Vršnik Cultural Groups of the Republic of Macedonia. In N. Tasić, C. Grozdanov (eds.), Homage to Milutin Garašanin. Serbian Academy of Sciences and Arts, Macedonian Academy of Sciences and Arts. SASA Special Editions. Belgrade: 171-191.
Stojanova Kanzurova E., Zdravkovski D. 2008. Katalog predmetov, Catalogue of object. In A. Šemrov, P. Turk (eds.), Neolitska umetnost na območju Republike Makedonije; Neolithic art in the Region of the Republic of Macedonia. Katalog razstave. Narodni muzej Slovenije. Ljubljana: 73-249.

Tasić N. N. 2006. Anzabegovo - A Key for the chronology of the Neolithic of the Central Balkans. In N. Tasić, C. Grozdanov (eds.), Homage to Milutin Garašanin. Serbian Academy of Sciences and Arts, Macedonian Academy of Sciences and Arts, SASA Special Editions. Belgrade: 159-169.

Zdravkovski D. 2006a. New Aspects of the Anzabegovo Vršnik Cultural Group. In N. Tasić, C. Grozdanov (eds.), Homage to Milutin Garašanin. Serbian Academy of Sciences and Arts, Macedonian Academy of Sciences and Arts, SASA Special Editions. Belgrade: 99-110.

2006b. The Cult of the Great Mother in the Neolithic Age in Macedonia. In Folia Archaeologica Balcanica I, In Honorem Verae Bitrakova Grozdanova. Faculty of Philosophy - Skopje. Institute for History of Art and Archaeology. Skopje: 60-61.

2008. Neolitska umetnost v Republiki Makedoniji. In A. Šemrov, P. Turk (eds.), Neolitska umetnost na območju Republike Makedonije/Neolithic art in the Region of the Republic of Macedonia. Katalog razstave. Narodni muzej Slovenije. Ljubljana: 39-70.

\section{back to contents}

